\title{
Drought modulated by North Atlantic Sea Surface Temperatures for the last 3,000 years along the northwestern Gulf of Mexico.
}

\author{
Daniel Livsey ${ }^{1}$, Alexander R. Simms ${ }^{1}$, Alexandra Hangsterfer ${ }^{2}$, Robert A. Nisbet ${ }^{3}$, Regina \\ DeWitt $^{4}$
}

${ }^{1}$ University of California at Santa Barbara, Department of Earth Science, 1006 Webb Hall - MC 9630, Santa Barbara, California 93106, USA

${ }^{2}$ University of California at San Diego, Scripps Institution of Oceanography, Geological Collections, 2310 Downwind Way, La Jolla, CA 92037

${ }^{3}$ University of California at Irvine, Predictive Analytics Certification Program, UC Irvine Extension, PO Box 6050, Irvine, CA, 92616, USA

${ }^{4}$ Department of Physics, East Carolina University, Howell Science Complex C-209, 1000 E $5^{\text {th }}$ St., Greenville, NC 27858, USA

\section{ABSTRACT}

In 2012 the most severe United States drought since the 1930's occurred, highlighting the need for a better understanding of the climate factors driving droughts. Spatial-temporal analysis of United States precipitation data from 1900 - 1999 indicates that the Atlantic Multidecadal Oscillation (AMO) primarily modulates drought frequency. Tree rings provide the highest resolution and most spatially distributed drought records beyond secular time-series; however, as most tree-ring records only extend to ca. 1,000 years before present (BP), a new broadly distributed, quantitative, multi-millennial, proxy of past drought is needed to determine if the AMO modulated drought across North America through the late Holocene. In this study, we develop a new quantitative drought proxy from a transfer function between X-Ray Fluorescence (XRF) derived elemental data from a Texas playa and a tree-ring drought record. Using this transfer function, a 954-year tree-ring drought record was extended to ca. 3,000 BP. Changes in the extended drought record correspond with timing of the Roman Climate Optimum, Medieval Warm Period, Little Ice Age, and changes in the AMO as recorded in a proxy record derived from North Atlantic ice-rafted debris. These results indicate that lacustrine-derived XRF element data can be used as a quantitative tool to reconstruct past drought records, and suggest that AMO modulated drought in southern Texas for the last 3,000 years. Additional studies using XRF- 
derived element data as a drought proxy are needed to determine the utility of this proxy in nonplaya lacustrine systems.

\section{INTRODUCTION}

Drought is one of the most costly natural disasters to affect society today (Cook et al., 2007). The development of quantitative and broadly distributed continental paleodrought records provides one approach to better predict the frequency of future droughts and thereby possibly ameliorate costs to society. Tree rings and speleothems provide such records; however, tree rings generally only extend to ca. 1,000 BP, and speleothem records are spatially limited (Cook and Krusic 2004; Asmerom et al., 2007). Another proxy found across continental settings is needed to increase our understanding of the spatial and temporal aspects of past droughts.

In this study we develop a quantitative, sub-decadal drought proxy by deriving a transfer function that relates the element distribution of Laguna Salada, Texas playa sediments to a nearby tree-ring drought record (Fig. 1). We use this transfer function to extend a 954 year treering drought record to ca. 3,000 BP to determine if changes in the AMO forced drought frequency within the study area beyond ca. 1,000 BP. Playas are an excellent locality to reconstruct drought records because they are found throughout continental semi-arid settings, are

limited in volume and thus sensitive to changes in precipitation, may persist for many millennia, and commonly contain sediments composed of interlaminated and interbedded muds and salts. The distribution of elements within playa sediments can be used as a proxy for past aridity because aridity affects playa geochemistry and hence the element distribution of lake sediments. 


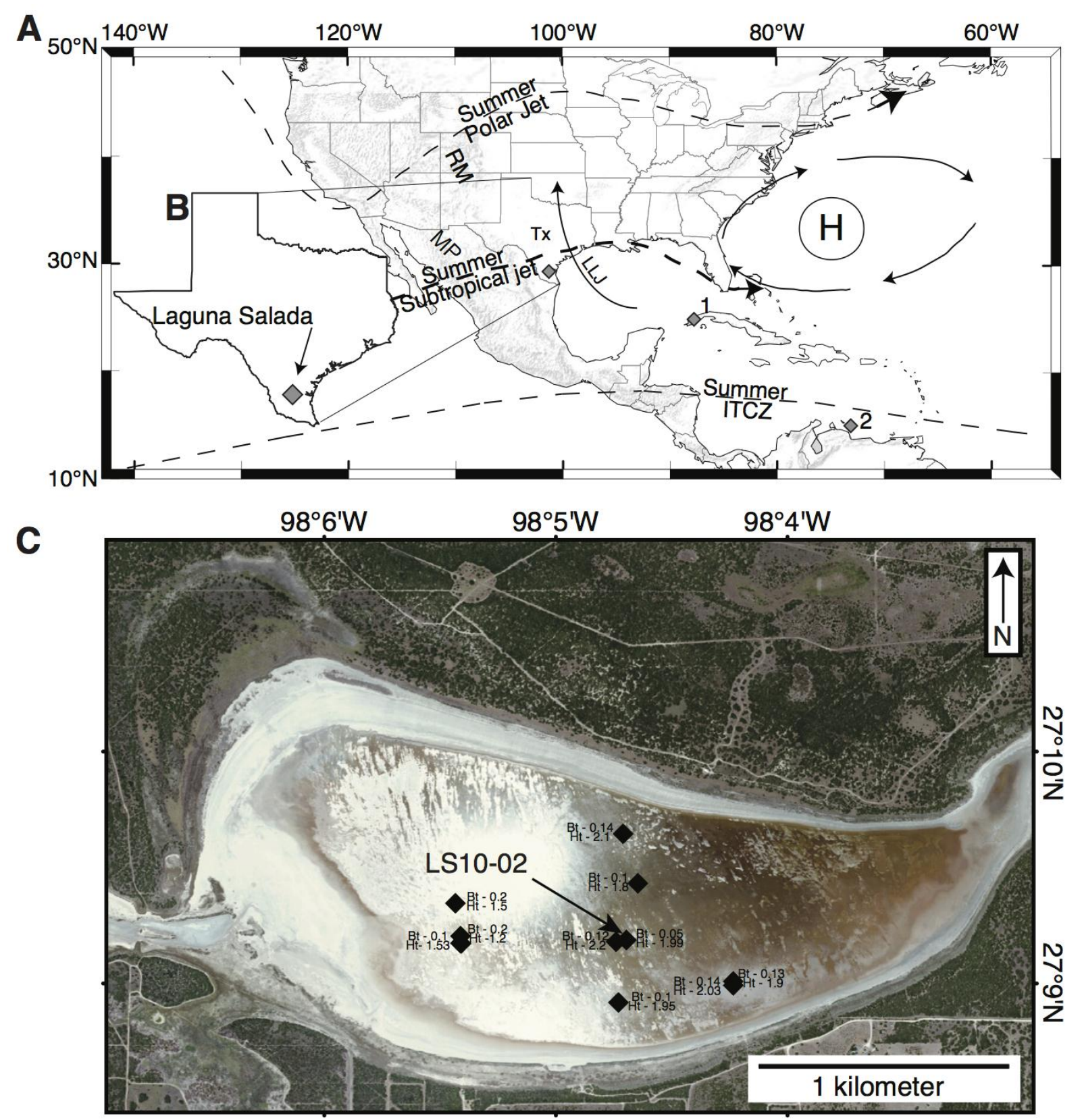

Figure 1. (A) Map indicating summer position of jet streams and Bermuda High (indicated by "H") and the Great Plains Low Level Jet indicated by "LLJ" (modified after MonterroSeranno et al., 2010). RM and MP indicate location of Rocky Moutain and Mexican Plateau respectively. Numbered diamonds indicate locations of proxy records shown in Figure 5 as follows: 1) Fensterer et al. (2013) and 2) Haug et al. (2001). (B) Inset indicating location of study area. (C) Satellite image of Laguna Salada indicating location of vibracores. Numerals with Bt and Ht labels indicate thickness of bioturbated core top and thickness of Holocene playa sediment in meters, respectively. Location of core LS10-02 used in this study indicated. 


\section{REGIONAL SETTING}

Laguna Salada is a playa located $35 \mathrm{~km}$ inland from Baffin Bay along the semi-arid southern Texas coastal plain (Fig. 1). Droughts in Texas are initiated by upper tropospheric anticyclonic disturbances originating from enhanced convection over the Rocky Mountain and Mexican Plateau (RMP) and maintained by surface processes through a soil moistureprecipitation positive feedback (Fig. 1; Myoung and Nielsen-Gammon 2010). The Great Plains low-level jet, the primary moisture source for Texas (Forman et al., 2001), is also limited with enhanced convection over the RMP (Higgins et al., 1997). Convection over the RMP, and thus the North American Monsoon, may be enhanced by direct tropospheric heating and/or via remote forcing of sea surface temperature (SST) anomalies in the Atlantic and/or Pacific (Higgins et al., 1997). Enhanced convection over the RMP may be driven by northward shifts in the Pacific and Bermuda highs (Higgins et al., 1997) driven by enhanced Hadley cell circulation and poleward shifts in the Intertropical Convergence Zone (ITCZ). A recently published foraminiferal-based proxy record of climate from Baffin Bay, TX along the southern Texas coastline suggests that these processes observed in the modern continued through the Holocene with enhanced North American Monsoon conditions corresponding to dry conditions in Baffin Bay (Buzas-Stephens et al., 2014).

\section{METHODS}

Tropical cyclones may ameliorate drought in Texas and across the Gulf of Mexico coastline (Maxwell et al., 2013). To determine the relative role of tropical cyclones on Laguna Salada hydrology we compared monthly dry and full playa phases, determined from aerial and satellite photos from 1972 to 2008, to monthly Palmer Drought Severity Index (PDSI) data and the number of land-falling hurricanes occurring within $100 \mathrm{~km}$ of the playa (Table 1). Chi-square statistics were computed between tropical cyclone, PDSI, and monthly dry/full data to determine if tropical cyclones and/or PDSI data exhibited statistically significant correlations with the dry/full data.

Ten vibracores were collected from Laguna Salada, Texas to determine the thickest and least bioturbated section of playa sediment (Fig. 1C). Visual description, line-scan photographs, and X-Ray core images were collected to document bioturbation and determine typical lamination thickness (Fig. 2A). An AVATECH® XRF core scanner was used to measure the relative abundances of 29 elements from the longest, $\sim 2 \mathrm{~m}$, and least bioturbated core, LS10-02 
(Fig. 2B). A 2-mm scanning interval was chosen given the mm-scale laminations observed in XRay core images (Fig. 2A). A paucity of organic matter precluded the collection of radiocarbon data, thus twenty-two optically stimulated luminescence (OSL) ages were obtained from quartz grains isolated from sand laminae within the core (Table 2). Optically stimulated luminescence (OSL) dating determines the time elapsed since the last sunlight exposure of a deposit, i.e. the time of deposition. A complete description of the method can be found, among others, in a review by Rhodes (2011) and a recent collection of encyclopedia entries (Rink and Thompson, 2015). The luminescence emitted by minerals under controlled light exposure is proportional to the absorbed radiation dose from radioactive isotopes in the deposit and cosmic radiation. The OSL age of a sample (i.e., burial time) is derived from: Age (ka) = Equivalent Dose (Gy) / Dose Rate $(\mathrm{Gy} / \mathrm{ka})$, where, the "equivalent dose", $\mathrm{D}_{\mathrm{E}}$ in units Gray $(\mathrm{Gy})$, is determined by comparing the natural luminescence signal with the signals obtained after known radiation exposures administered in the laboratory. The rate of natural irradiation, the "dose rate" in units Gy/ka, can be determined from the concentration of radioactive nuclides in the sediment.

The cores were cut in half in the darkroom under red-light conditions. OSL samples were taken from sandy layers, carefully avoiding material in direct contact with the core tubes. About $200 \mathrm{~g}$ of surrounding material (corresponding to $10 \mathrm{~cm}$ of the core) were obtained from the remaining core material for gamma spectrometry. Quartz separates (63-212 $\mu \mathrm{m})$ were prepared with standard techniques, and $3 \mathrm{~mm}$ multigrain aliquots were prepared on steel cups. Measurements were conducted using a Ris $\emptyset$ TL/OSL-DA-15 reader, Ris $\varnothing$ National Laboratory, with a bialkali PM tube (Thorn EMI 9635QB) and Hoya U-340 filters (290-370 nm). The built-in ${ }^{90} \mathrm{Sr} /{ }^{90} \mathrm{Y}$ beta source gives a dose rate of $(99.6 \pm 4.1) \mathrm{mGy} / \mathrm{s}$. Optical stimulation was carried out with blue LEDs (470 $\mathrm{nm}$ ), delivering $31 \mathrm{~mW} / \mathrm{cm}^{2}$ to the sample. IR stimulation was from an IR LED array at $875 \pm 80 \mathrm{~nm}$ with $36 \mathrm{~mW} / \mathrm{cm}^{2}$ power at the sample. The heating rate used was $5^{\circ} \mathrm{C} / \mathrm{s}$. Measurements were based on the single-aliquot regenerative-dose (SAR) procedure described by Murray and Wintle (2000), and Wintle and Murray (2006), with high temperature bleach (Murray and Wintle, 2003). Total equivalent dose $D_{\mathrm{e}}$ was determined with the common age model (Galbraith et al., 1999), where statistical errors were used as weights. The full uncertainty also includes $4.1 \%$ error for the source calibration.

$\mathrm{U}$, Th, and $\mathrm{K}$ concentrations in the samples were measured with high resolution Ge gamma spectrometry with a Reverse Electrode Coaxial Germanium detector from Canberra 
Industries, Inc. Water content was measured as received and appropriate error limits were adopted based on sampling conditions and annual precipitation. Disequilibria in the uranium decay chain were observed and accounted for in the calculation for the final age. The cosmic dose rate was calculated as described by Barbouti and Rastin (1983), Prescott and Stephan (1982), and Prescott and Hutton (1994).

Bchron, an open-source, nonparametric, Bayesian software tool was used to create $n$ possible age-models from the OSL ages (Fig. 3; see the appendix; Parnell et al., 2008). Bchron utilizes a Monte Carlo approach and stochastic piecewise linear interpolation to produce $n$ possible monotonic age-models (herein $n=10,000$ ) that are consistent with age-data (Parnell et al., 2008). This approach does not produce any single most probable age-model but rather produces a set of possible age-models within the bounds of the age data (Parnell et al., 2008). In addition to providing $n$ possible age-models Bchron, similar to other age-model software (e.g. $\mathrm{BCal}$ and $\mathrm{OxCal}$ ) automatically identifies statistical outliers (see Haslett and Parnell 2008 and refs. therein for statistical treatment).

Figure 2. (A) Core description of core LS10-02. (B) Line-scan image and X-ray image of core LS10-02 used in this study. Representative white carbonate clays $\left(\mathrm{CO}_{3}\right)$, microbial mats (MM), and gypsum (G) are indicated. (C) Drought prediction from ensemble of top 3 models (see Fig. 4K). (D) Z-transformed element intensities used as final predictor variables and tree-ring data from Cook and Krusic (2004) used as target variable. Note horizontal dashed lines correlating decrease and increase in Bromine, Lead, and Barium with wet and dry times respectively. See Figure 7 for bivariate plots of XRF and tree-ring data. 


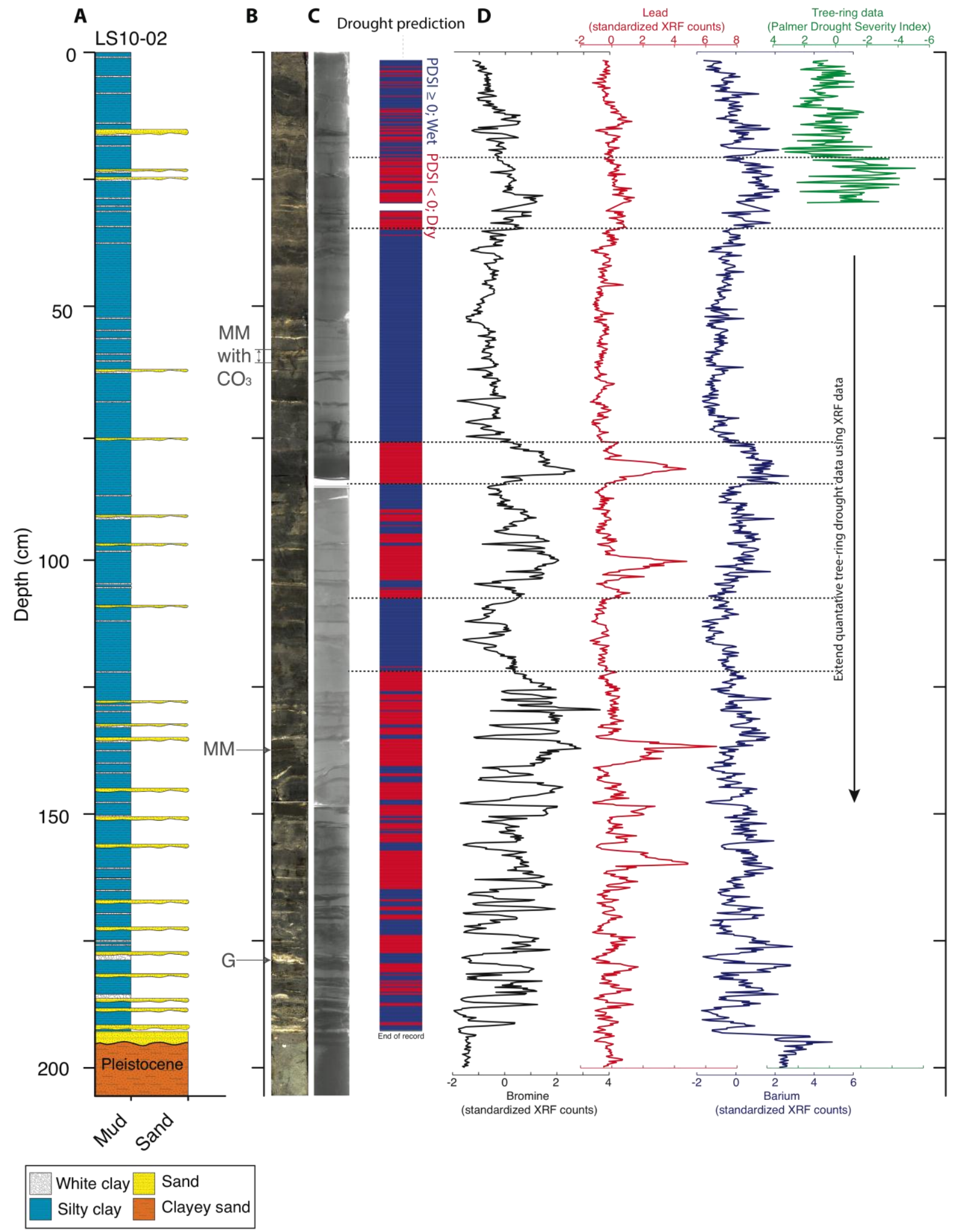

Page 7 of 31 
Based upon the median of the 10,000 age-models each $2 \mathrm{~mm}$ XRF measurement (henceforth, a case) represents between 4 and 10 years of deposition; therefore, annual tree-ring data obtained from Cook and Krusic (2004) and Cleveland et al. (2011) was aggregated into two separate time-series composed of unequal time-steps to correspond with the XRF time-series of LS10-02. The Cook and Krusic (2004) tree-ring record extends to 954 BP and is derived from regional tree-ring records tuned to modern June, July, and August (JJA) PDSI data (Fig. 2C). The Cleveland et al (2011) tree-ring record extends to $450 \mathrm{BP}$ and is tuned to modern June PDSI based only on tree-ring records from southern Texas.

In addition to the median-age model and since no singular age-model produced from Bchron is more probable than another (i.e. all age-models are equally possible within the $95 \%$ confidence interval that varies between \pm 25 years and \pm 250 years) an optimum-age model that maximizes simple correlation coefficients between the XRF data and each tree-ring record was also determined.. To determine an optimum-age model, the absolute value of all simple correlation coefficients between the XRF data and each tree-ring record were summed over all cases for each $n^{\text {th }}$ age-model. The coeval XRF/tree-ring time-series based upon the age-model with the greatest simple correlation coefficient sum and the median-age model were used in subsequent steps to derive the transfer function. This process was conducted for each tree-ring record separately with two optimum-age models produced for each record separately (i.e. one optimum-age model based on the Cook and Krusic 2004 record and one optimum-age model based on the Cleveland et al. 2011 record). For ages greater than the coeval XRF and tree-ring data (> $954 \mathrm{BP}$ and $>450 \mathrm{BP}$ ) the median age model was used (Fig. 3). 


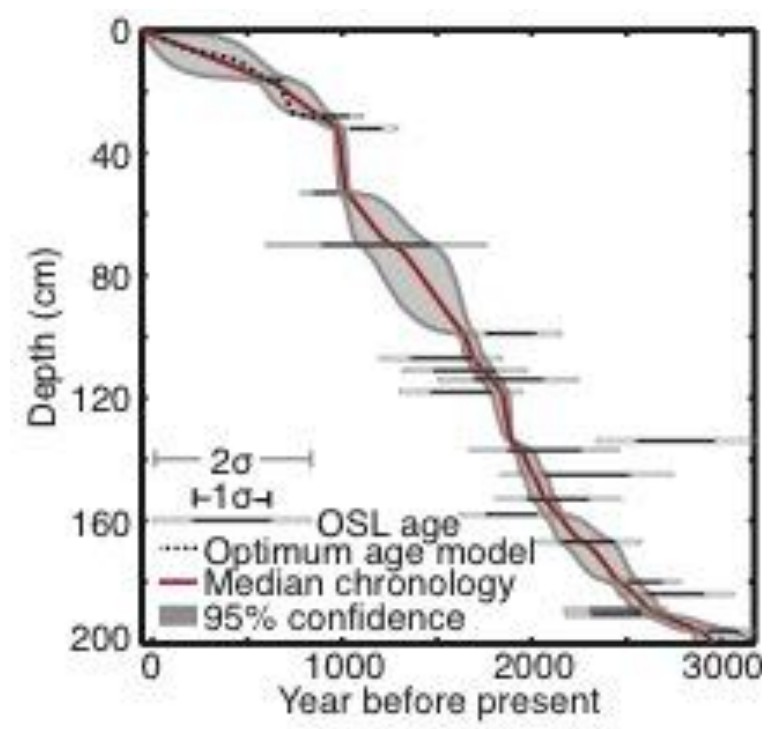

Figure 3. Age model for core LS10-02 showing one and two-sigma error from twenty-two optically stimulated luminescence (OSL) ages with $95 \%$ confidence range of Bchron age-model shaded. The optimum-age model shown is the optimum-age model based upon the Cook and Krusic (2004) tree-ring record. See Table 2 for OSL age data.

Transfer functions between the XRF data (predictor variables) and tree-ring drought data (target variable) were derived from a suite of 7 machine learning algorithms and 2 general discriminant analysis (GDA) models available in STATISTICA® (logit and normal). Transfer functions were derived using machine-learning algorithms because the relationship between XRF and tree-ring data is unknown. Machine learning algorithms detect highly non-linear relationships directly from data, without reliance upon assumptions made by standard statistical analysis techniques (see Birks et al., 2012 and references therein for a discussion of machine learning applications in paleolimnology).

To derive the transfer functions, the coeval XRF and tree-ring data were randomly subset into $60 \%$ training, $20 \%$ testing, and $20 \%$ validation datasets. Predictor variables (e.g. XRF data) and target variables (e.g. tree-ring data) were selected and models ran using only the training and testing subsets to derive the transform functions. Model outputs were compared against the heldout validation dataset and the validation accuracy (VA) for each model was computed. VA provides a quantifiable measure of model generalization, the ability of models to perform accurately on unseen data, and is a primary metric for model selection (Nisbet et al., 2009). The VA of the continuous target variable was computed using the simple correlation coefficient (R) between the model output and target variable of the validation dataset. The VA of a categorical target variable was computed by the ratio of correct classifications to the total number of cases in the validation dataset.

Algorithms were trained separately on the continuous tree-ring data and categorically transformed tree-ring data as target variables. The continuous PDSI tree-ring data measured was 
transformed into a categorical variable with negative PDSI designated as " 0 " (a dry year) and non-negative PDSI as "1" (a wet year). Determining which variables and appropriate variable transformations (e.g. ratios and log ratios of element intensities) to utilize as predictor variables is one of the most important steps in maximizing VA. Z-transformed element intensities, log ratios, element ratios and sediment lightness measured by line-scan camera were considered as possible predictor variables. Only z-transformed element intensities of elements with atomic numbers $>26$ were considered as predictor variables as Hennekam and Lang (2012) found that for elements with atomic numbers $\leq 26$ single element intensities measured by XRF can be influenced by sediment water content. A Chi-square statistic, a measure of dependence, and $p$ value was computed between each variable and coeval tree-ring data case to determine which variables to utilize as predictor variables. For details of each step described above see the appendix.

\section{RESULTS}

The OSL sample at $134 \mathrm{~cm}$ (Table 2), the only sample at the $2 \sigma$-range to indicate an agereversal, was identified by Bchron as a statistically significant outlier and was not utilized to produce the age-models. All OSL ages derived from samples with greater than 10 aliquots show no age inversions (Table 2). Age inversions occur in samples for which only a low number of aliquots (less than 10) was available for age calculation, including samples taken at $28 \mathrm{~cm}, 32$ $\mathrm{cm}, 70 \mathrm{~cm}, 99 \mathrm{~cm}, 107 \mathrm{~cm}, 134 \mathrm{~cm}, 191 \mathrm{~cm}$ (Table 2). Although these ages have larger errors Bchron did not select the ages as statistical outliers and were used to produce the $n$ age models.

Chi-squared analysis indicates that hurricane events do not exhibit a statistically significant relationship with dry/full phases ( $\mathrm{p}=0.12$; Table 1$)$ while PDSI data showed statistically significant correlations ( $\mathrm{p}=0.004$; Table 1 ). Lag variables, derived from averaging PDSI values and summing the number of tropical cyclone events for $n$ months prior to each dry/full month case, were used to analyze the longer-term relationships between playa dry/full phases, PDSI data, and tropical cyclones. Statistically significant correlations for all PDSI predictor lag variables were found for a time lag $(d t)$ of $d t=3$ months, 6 months, and 9 months while no statistically significant relationship is found for hurricane predictor lag variables for $d t=3$ months, 6 months, and 9 months (Table 1).

All six vibracores contained laminated and bedded sediments comprised of dark blue clays, microbial mats, white carbonate clays, quartz sand, and gypsum (Figs. 2A, 2B). Gypsum, 
comprised of $63 \mu \mathrm{m}$ to $120 \mu \mathrm{m}$, euhedral, psuedohexagonal, tabular-prismatic crystals, and carbonate clays deposited in association with mm-thick microbial mats were light-colored and interbedded with dark blue clay beds (Fig. 2B). The euhedral morphology of the gypsum crystals indicates that the crystals formed within the water column and not diagenetically (Mees et al., 2012). Hiatuses can bias proxy records in playa settings; however, VA $>90 \%$ (see below) and the absence of pedogenesis, induration, erosional lags, bioturbation, and mud crack structures in core LS10-02 suggest that hiatuses do not significantly impact the Laguna Salada depositional record at the temporal scale of $4-10$ years.

Z-transformed Barium (Ba), Lead $(\mathrm{Pb})$, and Bromine $(\mathrm{Br})$ element intensities exhibited the greatest Chi-square statistics in the median and optimum age-models and when utilized as predictor variables maximized VA for both tree-ring target variables. Element log ratios and ratios using both age models and sediment lightness exhibited lower Chi-square statistics and did not improve model VA. VA of models using $\mathrm{Ba}, \mathrm{Pb}$, and $\mathrm{Br}$ as predictor variables and both treering records as continuous target variables using both age models did not exceed $\mathrm{R}^{2}$ values of 0.3. VA of models using $\mathrm{Ba}, \mathrm{Pb}$, and $\mathrm{Br}$ as predictor variables and the Cook and Krusic (2004) transformed categorical tree-ring data as a target variable using the median-age model and optimized age-model exhibited accuracies ranging between $35 \%-77 \%$ and $53 \%-94 \%$ respectively. The Cleveland et al. (2011) record, when used as a target variable, exhibited VA between $50 \%-56 \%$ and $57 \%$ - 67\% for the median-age and optimum-age models respectively. Transfer functions determined using the optimum age model, $\mathrm{Ba}, \mathrm{Pb}$, and $\mathrm{Br}$ as the predictor variables, and the categorical tree-ring target variable derived from Cook and Krusic (2004) data were utilized to extend the final drought record because these model outputs exhibited the greatest VA.

The model outputs comprised of " 0 " for dry years and " 1 " for wet years were binned every 100 years for visual comparison. Overall, each model output using $\mathrm{Ba}, \mathrm{Pb}$, and $\mathrm{Br}$ as predictor variables exhibits a peak in drought frequency at ca. 1,000 BP and from ca. 1,500 BP to 2,600 BP (Fig. 4). For the final drought record the models with validation accuracies $>80 \%$ (logit GDA with 94\% VA, normal GDA with 94\% VA, and Naïve Bayes classifier with 80\% VA) were combined into an ensemble to increase the final model generalization (Fig. 2D; Fig. 5A; Nisbet et al., 2009). The three model outputs were combined into an ensemble by adding the probability of each case classification from the model outputs. 

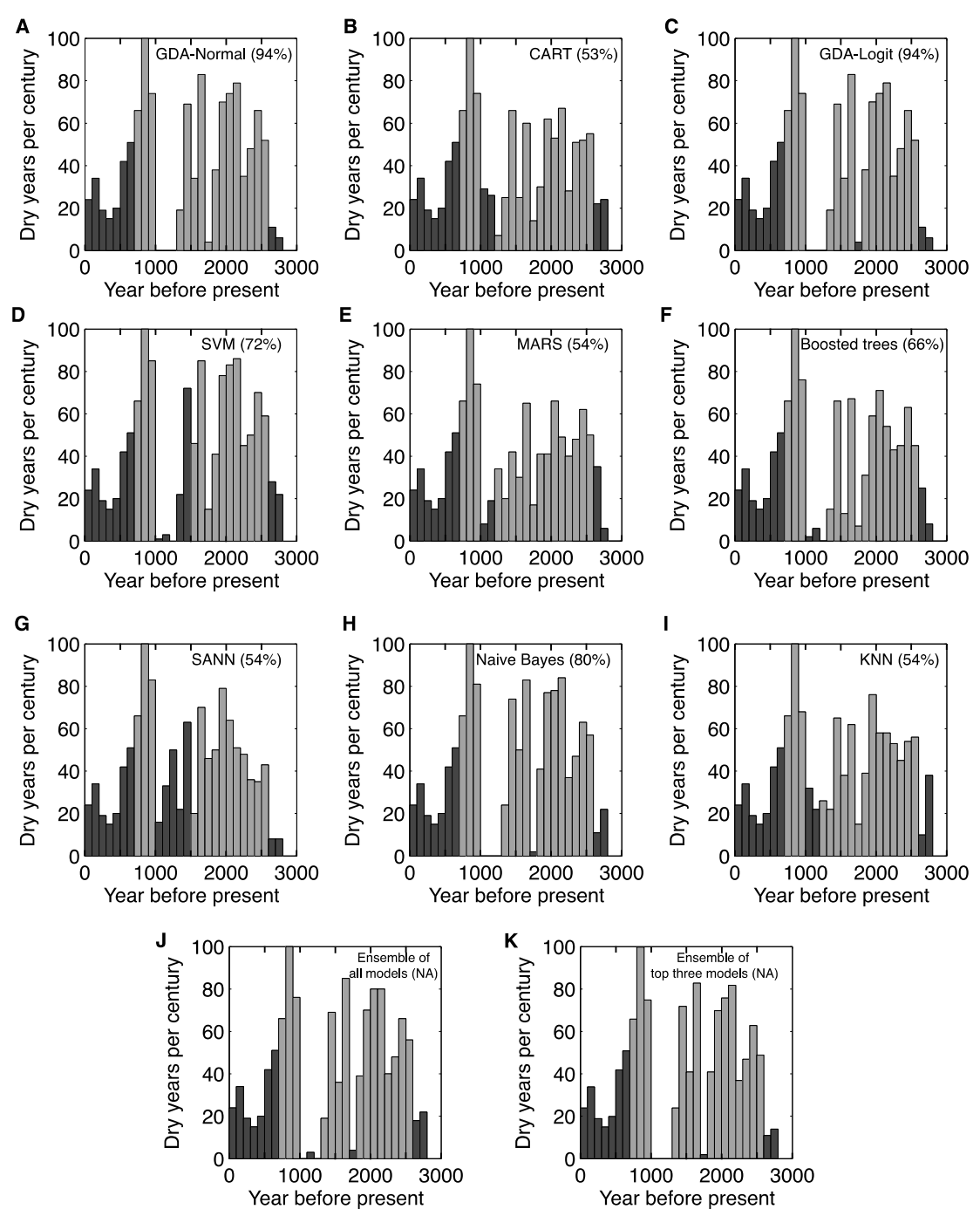

Figure 4. (A-I) Model drought predictions and validation accuracies in parenthesis from all models used in this study. Bars ca. 1,000 BP and from ca. 1,500 to 2,600 BP noted in text are shaded in lighter gray. Explanation for all abbreviations are as follows: Normal based general discriminant analysis (GDANormal), classification and regression trees (CART), logistic based GDA (GDA-logit), support vector machine (SVM), multivariate adaptive regression splines (MARS), Statistica artificial neural networks (SANN), naive bayes classifier (Naive Bayes), and k-nearest neighbors (KNN). (J) Ensemble of all models. (K) Ensemble of top three models, as measured by validation accuracies, including GDANormal, GDA-Logit, and Naive Bayes. 


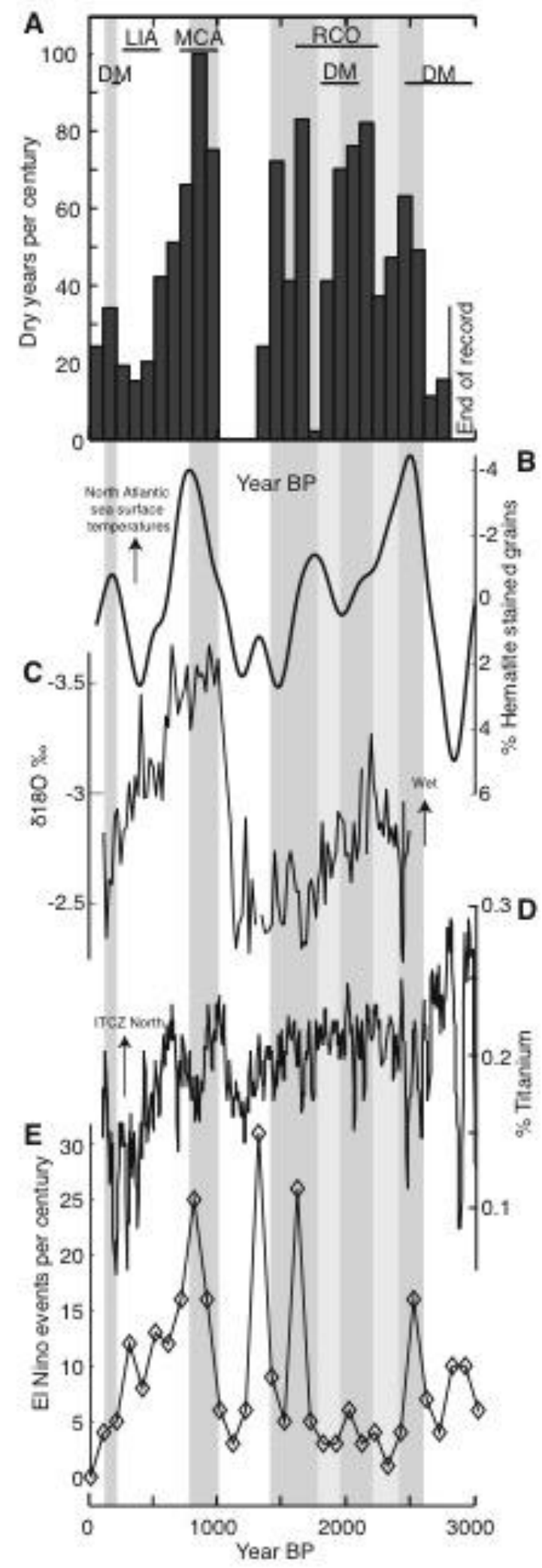

Figure 5. (A) Ensemble drought record binned at century intervals with timing of nearby coastal dune migration (DM; Forman et al., 2009), Little Ace Age (LIA) and Medieval Warm Period (MWP) (Mann et al., 2009), and Roman Climate Optimum (RCO; Weppner et al 2013 ) indicated by black bars. (B) North Atlantic ice-rafted debris record (ztransformed) from Bond et al. (2001). (C) Speleothem record from western Cuba from Fensterer et al. (2013). (D) Percent titanium is marine sediments from the Cariaco Basin interpreted as a proxy for the ITCZ from Haug et al. (2001). (E) El Niño events per century derived from sediments from Laguna Pallcacocha, Ecaudor (Moy et al., 2004). See Figure 1A for locations of A, C, and D. All proxies plotted from independent age-models in year before present (BP) with present at 1950 A.D. Vertical grey bars highlight correlations indicated in text. 


\section{DISCUSSION}

\section{(5.1) Laguna Salada hydrology}

The statistically significant correlations between PDSI data and Laguna Salada dry/full data and a lack of statistically significant correlations between hurricane data and Laguna Salada dry/full data indicate that precipitation sourced from the Great Plains low-level jet is more important in controlling Laguna Salada hydrology than tropical cyclones (Table 1). To determine why the Cleveland et al. (2011) record when used as a target variable exhibited lower VA than the Cook and Krusic (2004) record, we compared modern June, July, and August PDSI data to the Laguna Salada monthly dry/full phases (Table 3). Chi-squared statistics were computed between monthly PDSI data and Laguna Salada dry/full phases for $n$ months following each August from 1972 - 2003 (Table 3). For $n=3$, 6, and 9 months following August of each year the Laguna Salada categorical target variable was assigned either dry or full by vote (e.g. for 3 months after August of $y$ year if 2 of 3 months were dry then the entire 3 month period was assigned as dry; Table 3). June PDSI exhibited no statistically significant correlation with Laguna Salada dry/full data for $n=3,6$, and 9 months following each August ( $p=0.31$ to 0.49; Table 3). In comparison, July, August, and JJA PDSI variables exhibited statistically significant correlations at $n=3$ and 6 months with all p-values $\leq 0.05$ (Table 3). August PDSI was the only variable to exhibit statistically significant correlation with Laguna Salada dry/full data at $\mathrm{n}=9$ months ( $p=0.04$; Table 3).

Although Texas tree growth exhibits a greater correlation with June PDSI (Cleveland et al., 2011) the statistically significant correlation between Laguna Salada dry/full data and JJA PDSI, lack of statistically significant correlation between Laguna Salada dry/full data and June PDSI, and much higher VA using JJA PDSI tree-ring record suggests that playa hydrology is more sensitive to the composite JJA PDSI conditions. The lack of statistically significant correlation from June PDSI and statistically significant correlation from the averaged JJA PDSI indicates that composite JJA PDSI conditions is a better predictor of playa hydrology than June PDSI conditions alone. This interpretation is further supported by the analysis of modern precipitation and evaporation data indicating the maximum moisture imbalance, as measured by the ratio of monthly evaporation to precipitation, for the months of July to August occurs in July followed by August and June having the least moisture imbalance (Fig. 6). 
A

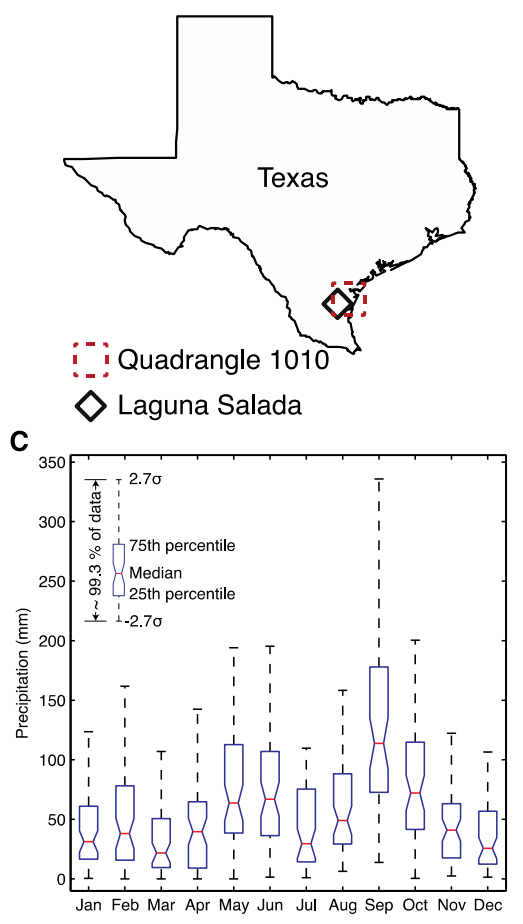

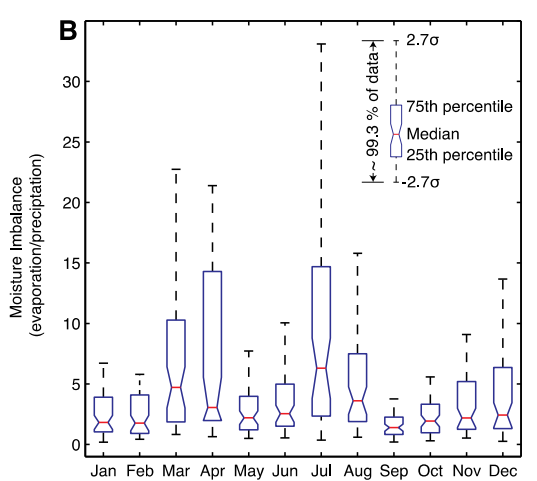

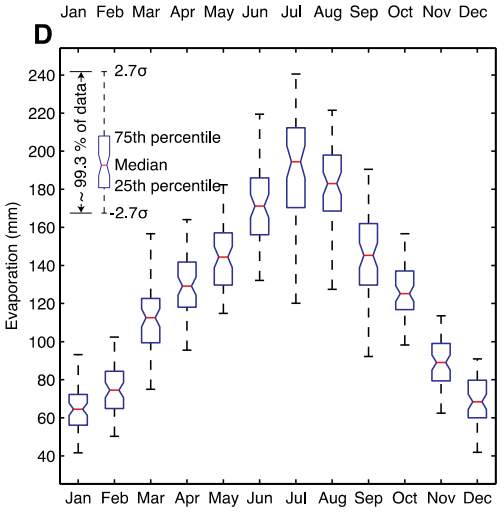

Figure 6. Modern precipitation and evaporation data for Texas Water Development Board quadrangle 1010, area covering Laguna Salada, for years 1954 to 2013. (A) Map indicating location of study area and quadrangle 1010. (B) Monthly moisture imbalance computed as ratio between monthly evaporation and monthly precipitation from quadrangle 1010. Note, for months June through August, largest moisture imbalance occurs in July and August. (C) Monthly precipitation for quadrangle 1010. (D) Monthly evaporation data for quadrangle 1010. Data downloaded from

http://www.twdb.texas.gov/surfacewater/conditions/evaporation/index.asp on Sept 9th,

\section{(5.2) Predictor variable selection}

Predictor variable selection was not based upon any a priori knowledge because of the lack of in situ measurements of playa or stream geochemistry. Instead predictor variables were selected solely upon the Chi-square statistic and VA. The statistically significant correlation between dry periods and $\mathrm{Pb}, \mathrm{Ba}$, and $\mathrm{Br}$ (Fig. 7) is expected as $\mathrm{Pb}$ is commonly sourced from soil dust aerosols that would increase during dry times (Shotyk et al., 1998) and Br and Ba are commonly found in association with evaporites (Kühn and Hsü, 1974). The statistically significant parametric (Pearson) and nonparametric (Spearman and Kendall) correlation 
coefficients are low; however, the high VA (> 90\%) and consistent model outputs (Fig. 4) demonstrate the ability of machine learning algorithms to detect non-linear relationships between $\mathrm{Pb}, \mathrm{Ba}, \mathrm{Br}$ and drought. The prediction of continuous tree-ring drought data may be improved by higher precision absolute age-dating (e.g. ${ }^{210} \mathrm{~Pb}$ age-dating); however, the low VA may also indicate that playa geochemistry measured by XRF core scanning does not appreciably change until PDSI values fall below or rise above 0 . Future studies using playa-derived XRF data as a drought proxy should independently determine predictor variables and models as the relationship between lake geochemistry, sedimentation, and aridity may vary by locality.
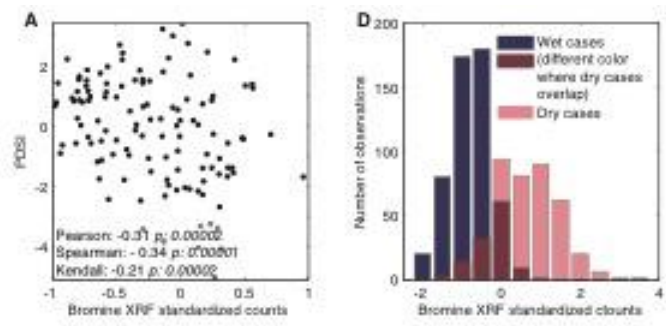

Figure 7. (A-C) Plots between predictor variables, $\mathrm{Br}, \mathrm{Pb}$, and $\mathrm{Ba}$, used in this study against Cook and Krusic (2004) site 182 continuous tree-ring data.

Parametric and nonparametric correlation coefficients with respective $\mathrm{p}$ values given. Note statistical significance for all measures of
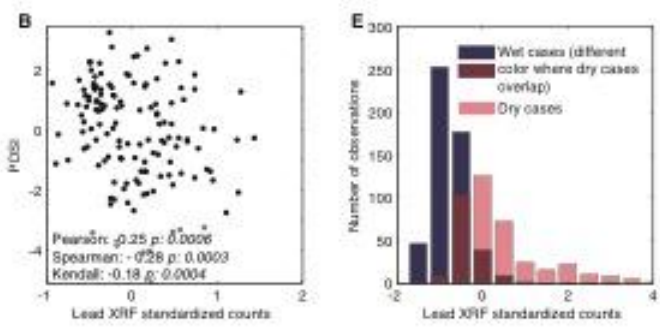
dependence. Grey circles occur where text providing the correlation coefficients overlaps data. (D-F) Histograms of predictor variables binned with cases wherein case was assigned as wet shown in dark-colored bars and cases wherein case was assigned as dry shown in light-colored
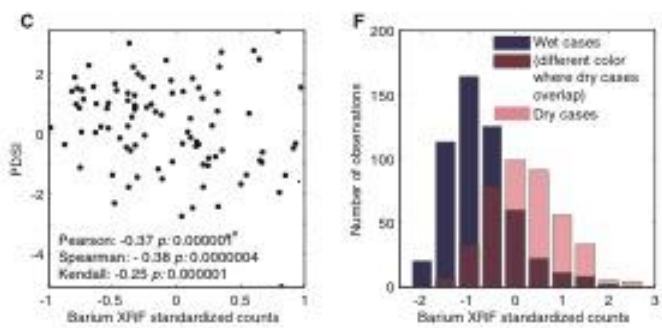
bars. Note dry cases have overall increase in $\mathrm{Br}$, $\mathrm{Pb}$, and $\mathrm{Ba} \mathrm{XRF}$ counts.

\section{(5.3) Ensemble drought record and paleoclimate comparisons}

The ensemble drought record compares well with the timing of regionally-documented periods of climatic change. Periods of increased drought frequency occur during the Roman Climate Optimum, a time period of drier conditions in the western and midwesern United States (Weppner et al., 2013), the Medieval Warm Period, a time period of overall drier conditions in south Texas (Cook et al., 2007; Mann et al., 2009), and periods of nearby ( $<50 \mathrm{~km}$ away) dune reactivation (Forman et al. 2009; Fig. 5A). Conversely, time periods of decreased drought 
frequency occur during the Little Ice Age, a time period of overall wetter conditions in south Texas (Mann et al., 2009; Fig. 5A).

The ensemble drought record is compared to pertinent paleoclimate time-series below to further validate the ensemble drought record. Correlation coefficients are not calculated between the paleoclimate time-series shown in Fig. 5 since each record has age-models with variable uncertainties on the order of 10's to 100's of years. Rather, paleoclimate time-series are compared for overall correspondence (e.g. the increase in drought frequency (Fig. 5A) and icerafted debris (Fig. 5B) from ca. $2.5 \mathrm{ka}$ to ca. $1.3 \mathrm{ka}$ ). Caution should be exercised when comparing high-order centennial- and decadal-scale frequency changes in these records. For example, the oscillation in ice-rafted debris (Fig. 5B) and \% Titanium (Fig. 5D) at ca. 2.5 ka, may correspond especially when considering conceptual linkages put-forth below; however, given the uncertainties in each age-model confidence in centennial-scale correspondence should remain tentative.

McCabe et al (2004) conducted principal component analysis on precipitation data from 1900 - 1999 AD over the conterminous United States and found that variations in the AMO and PDO accounted for $52 \%$ of the spatial-temporal variance in multidecadal drought frequency. The AMO phase primarily determined drought frequency while the PDO phase primarily determined the spatial distribution of drought (McCabe et al., 2004). To determine if the AMO phase modulated drought frequency in southern Texas beyond 1900 AD we compare the ensemble drought record to a proxy for past AMO variability (Fig. 5B). We utilize the North Atlantic icerafted debris record from Bond et al. (2001) since Feng et al. (2009) found that this record positively correlated to the first principal component of Atlantic SST derived from 24 SST proxy records from the Atlantic Ocean from $\sim 30^{\circ} \mathrm{S}$ to $75^{\circ} \mathrm{N}$. For the entire record decreases in icerafted debris indicative of warmer North Atlantic SST and more positive AMO phases corresponds to increased drought frequency in the ensemble drought record (Fig. 5B). The correspondence between ice-rafted debris and the ensemble drought record suggests that AMO variability modulated drought frequency in southern Texas for the last 3,000 yrs. Holocene precipitation records derived from speleothems from the Caribbean (Fensterer et al., 2013; Kilbourne et al. 2008) and Mexico (Bernal et al., 2011) noted a similar correspondence to North Atlantic ice-rafted debris records and broadly follow the ensemble drought record (Fig. 5C). 
The AMO is thought to be driven by changes in Atlantic meridional overturning circulation (AMOC; Dima and Lohmann, 2007; Fensterer et al., 2013) and therefore may affect drought over southern Texas via changes in the mean latitudinal position of the ITCZ and/or by changes in precipitation delivery from the Great Plains low-level jet (Toomey et al., 1993). During enhanced AMOC the North Atlantic warms, leading to positive AMO phases, increased Hadley cell circulation, northward shift of the ITCZ and subtropical jet, enhanced convection over the RMP, and increased drought over southern Texas. Numerous geologic archives indicate that the mean latitudinal position of the ITCZ shifted through the Holocene on millennial to subcentennial timescales (Haug et al., 2001; Poore et al., 2003). Overall, drought frequency, as recorded by the ensemble drought record, increases with northerly shifts in the ITCZ as indicated by a proxy record from the Cariaco Basin (Fig. 5D).

Northerly shifts in the subtropical jet during positive AMO phases may also affect drought in southern Texas via modulation of the Great Plains low-level jet. A recent study of secular precipitation and SST data from 1979 - 2010 AD indicates that the Great Plains lowlevel jet, the primary moisture source for southern Texas, may be modulated by the strength of the Bermuda High (Zhu and Liang 2012). During northerly shifts of the subtropical jet the Bermuda High is displaced westward resulting in atmospheric pressure changes that lead to increased surface air temperatures over Texas and precipitation displacement from the Gulf of Mexico into the central United States (Zhu and Liang 2012). Although the authors found that east Pacific SST had the greatest correlation with the zonal position of the Bermuda High, enhanced AMOC leading to positive AMO phases may also lead to a strengthening and westward displacement of the Bermuda High.

Although we focus on the North Atlantic SST, the role that Pacific SST have upon the mean latitudinal position of the ITCZ and therefore convection over the RMP and zonal position of the Bermuda High cannot be ignored. Decreased El Nino Southern Oscillation (ENSO) and/or PDO may also drive northward shifts in the ITCZ (Haug et al., 2001). Comparison of the ensemble drought record to an ENSO proxy record from Lake Laguna Pallcacocha in the southern Ecuadorian Andes indicates that overall drier conditions from ca. $1.3 \mathrm{ka}$ to $2.7 \mathrm{ka}$ and a wetter period from ca. $1.3 \mathrm{ka}$ to $1.0 \mathrm{ka}$ correspond to decreased and increased ENSO variability respectively, suggesting that Pacific SST may have also modulated drought during this time (Fig. 5E). The increase in ENSO ca. $1.0 \mathrm{ka}$ and concomitant increase in dry conditions as indicated by 
the ensemble drought record (Fig. 5E) however, is not expected as increased ENSO generally leads to enhanced precipitation over the study area (Li et al., 2014). Li et al (2014) noted that ENSO phasing has a non-stationary effect on drought over the study area. The increase in drought concomitant with increased ENSO ca. 1.0 ka may reflect a time wherein the negative correlation between ENSO and drought was dominant and/or when the positive AMO phase during this time was a more dominant control on drought than ENSO.

Correlation coefficients are not calculated between the paleoclimate time-series shown in Fig. 5 since each record has age-models with variable uncertainties on the order of 10's to 100's of years. Rather, paleoclimate time-series are compared for overall correspondence (e.g. the increase in drought frequency and ice-rafted debris from ca. $2.5 \mathrm{ka}$ to ca. $1.3 \mathrm{ka}$ ). Caution should be exercised when comparing high-order frequency changes in these records. For example, the increase in the drought frequency (Fig. 5A) and ice-rafted debris (Fig. 5D) at ca. 2.5 ka, may correspond with the peak in \% Titanium (Fig. 5D) just before this in age especially when considering conceptual linkages put-forth above; however, given the uncertainties in each agemodel confidence in correspondence should remain tentative.

\section{CONCLUSION}

Correspondence between the North Atlantic ice rafted debris record, a proxy for North Atlantic SST, and the Laguna Salada drought record suggest that the AMO modulated drought over southern Texas. The AMO modulated drought over the study area possibly via shifts in the ITCZ, which enhanced subsidence over the study area, and/or by decreasing precipitation delivery from the Great Plains low-level jet. Although the role of Pacific SST on Texas drought should not be ignored, this study suggests that the AMO was a dominant driver of drought frequency over southern Texas for the last 3,000 yr. XRF element data derived from playas are

an excellent proxy for reconstructing past drought frequency and may provide the opportunity to extend quantitative paleodrought proxies throughout continental settings and through the Holocene.

\section{ACKNOWLEDGMENTS}

Funded by grants from the National Science Foundation (NSF) (EAR 0921963) and NSF Graduate Research Fellowship Grant No. DGE-1144085. We also wish to thank the landowners around Laguna Salada for access to the site. Anna Cruse, Emma Hansen, Taylor Troiani, and Greg Federko helped in the collection of cores. 


\section{REFERENCES CITED}

Asmerom, Y., Polyak, V., Burns, S., and Rassmussen, J., 2007, Solar forcing of Holocene climate: New insights from a speleothem record, southwestern United States: Geology, v. 35, no. 1, p. $1-4$.

Barbouti, A., Rastin, B., 1983. A Study of the Absolute Intensity of Muons at Sea Level and under Various Thicknesses of Absorber. Journal of Physics G: Nuclear Physics, 9: 15771595.

Bernal, J. P., Lachniet, M., McCulloch, M., Mortimer, G., Morales, P., and Cienfuegos, E., 2011, A speleothem record of Holocene climate variability from southwestern Mexico: Quaternary Research, v. 75, no. 1, p. 104-113.

Birks, H. J. B., Lotter, A. F., Juggins, S., and Smol, J.P, 2012, Tracking environmental change using lake sediments, Data Handling Numerical Techniques, Volume 5: Dordrecht, Springer, 745 p.

Bond, G., Kromer, B., Beer, J., Muscheler, R., Evans, M. N., Showers, W., Hoffmann, S., LottiBond, R., Hajdas, I., and Bonani, G., 2001, Persistent solar influence on north Atlantic climate during the Holocene: Science, v. 294, no. 5549, p. 2130-2136.

Buzas-Stephens, P., Livsey, D. N., Simms, A. R., and Buzas, M. A., 2014, Estuarine foraminifera record Holocene stratigraphic changes and Holocene climate changes in ENSO and the North American monsoon: Baffin Bay, Texas: Palaeogeography, Palaeoclimatology, Palaeoecology, v. 404, no. 0, p. 44-56.

Cleveland, M.K, Votteler, T.H., Stahle, D.K., et al., 2011, Extended Chronology of Drought in South Central, Southeastern and West Texas: Texas Water Journal, v. 2, no. 1, p. 54-96

Collins, M., Botzet, A., Carril, A. F., Drange, H., Jouzeau, A., Latif, M., Masina, S., Otteraa, O. H., Pohlmann, H., Sorteberg, A., Sutton, R., and Terray, L., 2006, Interannual to decadal 
climate predictability in the North Atlantic: A multimodel-ensemble study: Journal of Climate, v. 19, no. 7, p. 1195-1203.

Cook, E. R., and Krusic, P. J., 2004, The North American Drought Atlas: Lamont-Doherty Earth Observatory and the National Science Foundation.

Cook, E. R., Seager, R., Cane, M. A., and Stahle, D. W., 2007, North American drought: Reconstructions, causes, and consequences: Earth-Science Reviews, v. 81, no. 1-2, p. 93-134.

Delworth, T. L., Manabe, S., and Stouffer, R. J., 1997, Multidecadal climate variability in the Greenland Sea and surrounding regions: A coupled model simulation: Geophysical Research Letters, v. 24, no. 3, p. 257-260.

Dima, M., and Lohmann, G., 2007, A Hemispheric Mechanism for the Atlantic Multidecadal Oscillation: Journal of Climate, v. 20, no. 11, p. 2706-2719.

Feng, S., Hu, Q., and Oglesby, R. J., 2009, AMO-like variations of holocene sea surface temperatures in the North Atlantic Ocean: Climate of the Past Discussions, v. 5, no. 6, p. 2465-2496.

Fensterer, C., Scholz, D., Hoffmann, D. L., Spotl, C., Schroder-Ritzrau, A., Horn, C., Pajon, J. M., and Mangini, A., 2013, Millennial-scale climate variability during the last $12.5 \mathrm{ka}$ recorded in a Caribbean speleothem: Earth and Planetary Science Letters, v. 361, p. 143-151.

Forman, S. L., Nordt, L., Gomez, J., and Pierson, J., 2009, Late Holocene dune migration on the south Texas sand sheet: Geomorphology, v. 108, no. 3-4, p. 159-170.

Galbraith, R. F., Roberts, R. G., Laslet, G. M., Yoshida, H., and Olley, J. M., 1999, Optical dating of single and multiple grains of quartz from Jinmium rock shelter, northern Australia: Part I, Experimental design and statistical models: Archaeometry, v. 41, p. 339-364. 
Haug, G. H., Hughen, K. A., Sigman, D. M., Peterson, L. C., and Rohl, U., 2001, Southward migration of the intertropical convergence zone through the Holocene: Science, v. 293, no. 5533, p. 1304-1308.

Haslett, J., and Parnell, A., 2008, A simple monotone process with application to radiocarbondated depth chronologies: Journal of the Royal Statistical Society: Series C (Applied Statistics), v. 57 , no. 4, p. 399-418.

Hennekam, R., and de Lange, G., 2012, X-ray fluorescence core scanning of wet marine sediments: methods to improve quality and reproducibility of high-resolution paleoenvironmental records: Limnology and Oceanography-Methods, v. 10, p. 991-1003.

Higgins, R. W., Yao, Y., and Wang, X. L., 1997, Influence of the North American Monsoon System on the U.S. Summer Precipitation Regime: Journal of Climate, v. 10, no. 10, p. 26002622.

Kilbourne, K. H., Quinn, T. M., Webb, R., Guilderson, T., Nyberg, J., and Winter, A., 2008, Paleoclimate proxy perspective on Caribbean climate since the year 1751: Evidence of cooler temperatures and multidecadal variability: Paleoceanography, v. 23 , no. 3.

Knight, J. R., Allan, R. J., Folland, C. K., Vellinga, M., and Mann, M. E., 2005, A signature of persistent natural thermohaline circulation cycles in observed climate: Geophysical Research Letters, v. 32, no. 20.

Kühn, R., and Hsü, K. J., 1974, Bromine Content of Mediterranean Halite: Geology, v. 2, no. 5, p. 213-216.

Li, J., Xie, S.-P., and Cook, E. R., 2014, El Niño phases embedded in Asian and North American drought reconstructions: Quaternary Science Reviews, v. 85, no. 0, p. 20-34. 
Mann, M. E., Zhang, Z., Rutherford, S., Bradley, R. S., Hughes, M. K., Shindell, D., Ammann, C., Faluvegi, G., and Ni, F., 2009, Global signatures and dynamical origins of the Little Ice Age and Medieval Climate Anomaly: Science, v. 326, no. 5957, p. 1256-1260.

Maxwell, J. T., Ortegren, J. T., Knapp, P. A., and Soulé, P. T., 2013, Tropical Cyclones and Drought Amelioration in the Gulf and Southeastern Coastal United States: Journal of Climate, v. 26, no. 21, p. 8440-8452.

McCabe, G. J., Palecki, M. A., and Betancourt, J. L., 2004, Pacific and Atlantic Ocean influences on multidecadal drought frequency in the United States: Proc Natl Acad Sci U S A, v. 101, no. 12 , p. $4136-4141$.

Mees, F., Casteneda, C., Herrero, J., and Van Ranst, E., 2012, The Nature and Significance of Variations In Gypsum Crystal Morphology In Dry Lake Basins: Journal of Sedimentary Research, v. 82, no. 1, p. 37-52.

Montero-Serrano, J. C., Bout-Roumazeilles, V., Sionneau, T., Tribovillard, N., Bory, A., Flower, B. P., Riboulleau, A., Martinez, P., and Billy, I., 2010, Changes in precipitation regimes over North America during the Holocene as recorded by mineralogy and geochemistry of Gulf of Mexico sediments: Global and Planetary Change, v. 74, no. 3-4, p. 132-143.

Moy, C. M., Seltzer, G. O., Rodbell, D. T., and Anderson, D. M., 2002, Variability of El Nino/Southern Oscillation activity at millennial timescales during the Holocene epoch: Nature, v. 420, no. 6912, p. 162-165.

Murray, A. S. and A.G. Wintle (2000) .Luminescence dating of quartz using an improved single-aliquot regenerative-dose protocol. Radiation Measurements 32, 57-73.

Murray, A.S.,Wintle, A.G., (2003). The single aliquot regenerative dose protocol: potential for improvements in reliability. Radiat. Meas. 37, 377-381. 
Myoung, B., and Nielsen-Gammon, J. W., 2010, The Convective Instability Pathway to Warm Season Drought in Texas. Part II: Free-Tropospheric Modulation of Convective Inhibition: Journal of Climate, v. 23, no. 17, p. 4474-4488.

Nisbet, R., Elder, J., and Miner, G., 2009, Handbook of statistical analysis and data mining applications: Amsterdam, Academic Press, 824 p.

Parnell, A. C., Haslett, J., Allen, J. R. M., Buck, C. E., and Huntley, B., 2008, A flexible approach to assessing synchroneity of past events using Bayesian reconstructions of sedimentation history: Quaternary Science Reviews, v. 27, no. 19-20, p. 1872-1885.

Poore, R. Z., Dowsett, H. J., Verardo, S., and Quinn, T. M., 2003, Millennial- to century-scale variability in Gulf of Mexico Holocene climate records: Paleoceanography, v. 18, no. 2, p. 1048.

Prescott, J.R., Hutton, J.T., 1994. Cosmic ray contributions to dose rates for luminescence and ESR dating: large depths and long-term time variations. Radiation Measurements 23, 497500.

\section{Prescott, J.R., Stephan, L.G., 1982. The contribution of cosmic radiation to the environmental dose for thermoluminescence dating. PACT 6, 17-25.}

Rhodes, E.J., 2011. Optically Stimulated Luminescence Dating of Sediments over the Past 200,000 Years. Annual Review of Earth and Planetary Sciences 39, 461-488.

Rink, W.J and Thompson, J.W. (Eds.) Encyclopedia of Scientific Dating Methods. Springer Netherlands, Dordrecht. 978p.

Shotyk, W., Weiss, D., Kramers, J. D., Frei, R., Cheburkin, A. K., Gloor, M., and Reese, S., 2001, Geochemistry of the peat bog at Etang de la Gruère, Jura Mountains, Switzerland, and 
its record of atmospheric $\mathrm{Pb}$ and lithogenic trace metals ( $\mathrm{Sc}, \mathrm{Ti}, \mathrm{Y}, \mathrm{Zr}$, and REE) since 12,370 14C yr BP: Geochimica et Cosmochimica Acta, v. 65, no. 14, p. 2337-2360.

Toomey, R. S., Blum, M. D., and Valastro, S., 1993, Late Quaternary Climates and Environments of the Edwards Plateau, Texas: Global and Planetary Change, v. 7, no. 4, p. 299-320.

Weppner, K. N., Pierce, J. L., and Betancourt, J. L., 2013, Holocene fire occurrence and alluvial responses at the leading edge of pinyon-juniper migration in the Northern Great Basin, USA: Quaternary Research, v. 80, no. 2, p. 143-157.

Wintle, A.G., Murray, A.S. (2006). A review of quartz optically stimulated luminescence characteristics and their relevance in single-aliquot regeneration dating protocols. Radiation Measurements 41, 369-391.

Zhu, J., and Liang, X. Z., 2012, Impacts of the Bermuda High on Regional Climate and Ozone over the United States: Journal of Climate, v. 26, no. 3, p. 1018-1032.

\section{FIGURE CAPTIONS}

Figure 1. (A) Map indicating summer position of jet streams and Bermuda High (indicated by "H") and the Great Plains Low Level Jet indicated by "LLJ" (modified after Monterro-Seranno et al., 2010). RM and MP indicate location of Rocky Moutain and Mexican Plateau respectively. Numbered diamonds indicate locations of proxy records shown in Figure 5 as follows: 1) Fensterer et al. (2013) and 2) Haug et al. (2001). (B) Inset indicating location of study area. (C) Satellite image of Laguna Salada indicating location of vibracores. Numerals with Bt and $\mathrm{Ht}$ labels indicate thickness of bioturbated core top and thickness of Holocene playa sediment in meters, respectively. Location of core LS10-02 used in this study indicated.

Figure 2. (A) Core description of core LS10-02. (B) Line-scan image and X-ray image of core LS10-02 used in this study. Representative white carbonate clays $\left(\mathrm{CO}_{3}\right)$, microbial mats (MM), 
and gypsum (G) are indicated. (C) Drought prediction from ensemble of top 3 models (see Fig. 4K). (D) Z-transformed element intensities used as final predictor variables and tree-ring data from Cook and Krusic (2004) used as target variable. Note horizontal dashed lines correlating decrease and increase in Bromine, Lead, and Barium with wet and dry times respectively. See Figure 7 for bivariate plots of XRF and tree-ring data.

Figure 3. Age model for core LS10-02 showing one and two-sigma error from twenty-two optically stimulated luminescence (OSL) ages with 95\% confidence range of Bchron age-model shaded. The optimum-age model shown is the optimum-age model based upon the Cook and Krusic (2004) tree-ring record. See Table 2 for OSL age data.

Figure 4. (A-I) Model drought predictions and validation accuracies in parenthesis from all models used in this study. Bars ca. 1,000 BP and from ca. 1,500 to 2,600 BP noted in text are shaded in lighter gray. Explanation for all abbreviations are as follows: Normal based general discriminant analysis (GDA-Normal), classification and regression trees (CART), logistic based GDA (GDA-logit), support vector machine (SVM), multivariate adaptive regression splines (MARS), Statistica artificial neural networks (SANN), naive bayes classifier (Naive Bayes), and k-nearest neighbors (KNN). (J) Ensemble of all models. (K) Ensemble of top three models, as measured by validation accuracies, including GDA-Normal, GDA-Logit, and Naive Bayes.

Figure 5. (A) Ensemble drought record binned at century intervals with timing of nearby coastal dune migration (DM; Forman et al., 2009), Little Ace Age (LIA) and Medieval Warm Period (MWP) (Mann et al., 2009), and Roman Climate Optimum (RCO; Weppner et al 2013) indicated by black bars. (B) North Atlantic ice-rafted debris record (z-transformed) from Bond et al. (2001). (C) Speleothem record from western Cuba from Fensterer et al. (2013). (D) Percent titanium is marine sediments from the Cariaco Basin interpreted as a proxy for the ITCZ from Haug et al. (2001). (E) El Niño events per century derived from sediments from Laguna Pallcacocha, Ecaudor (Moy et al., 2004). See Figure 1A for locations of A, C, and D. All proxies plotted from independent age-models in year before present (BP) with present at 1950 A.D. Vertical grey bars highlight correlations indicated in text. 
Figure 6. Modern precipitation and evaporation data for Texas Water Development Board quadrangle 1010, area covering Laguna Salada, for years 1954 to 2013. (A) Map indicating location of study area and quadrangle 1010. (B) Monthly moisture imbalance computed as ratio between monthly evaporation and monthly precipitation from quadrangle 1010. Note, for months June through August, largest moisture imbalance occurs in July and August. (C) Monthly precipitation for quadrangle 1010. (D) Monthly evaporation data for quadrangle 1010. Data downloaded from http://www.twdb.texas.gov/surfacewater/conditions/evaporation/index.asp on Sept 9th, 2014.

Figure 7. (A-C) Plots between predictor variables, $\mathrm{Br}, \mathrm{Pb}$, and $\mathrm{Ba}$, used in this study against Cook and Krusic (2004) site 182 continuous tree-ring data. Parametric and nonparametric correlation coefficients with respective $\mathrm{p}$ values given. Note statistical significance for all measures of dependence. Grey circles occur where text providing the correlation coefficients overlaps data. (D-F) Histograms of predictor variables binned with cases wherein case was assigned as wet shown in dark-colored bars and cases wherein case was assigned as dry shown in light-colored bars. Note dry cases have overall increase in $\mathrm{Br}, \mathrm{Pb}$, and $\mathrm{Ba}$ XRF counts.

\section{TABLES}




\begin{tabular}{|c|c|c|}
\hline \multicolumn{3}{|l|}{ dry/full phases } \\
\hline \multicolumn{3}{|l|}{ Explanation } \\
\hline \multicolumn{3}{|c|}{$\begin{array}{l}\text { Measure of dependence, using Chi-square statistic, between given variable and lag variables and } \\
\text { monthly Laguna Salada Dry/Full phases derived from aerial and satelite imagery from } 1972 \text { to } 2003 \text {. }\end{array}$} \\
\hline \multicolumn{3}{|c|}{$\begin{array}{l}\text { Palmer Drought Severity Index (PDSI) data for South Texas Region } 9 \text { and downloaded from: } \\
\text { http://www7.ncdc.noaa.gov/CDO/CDODivisionalSelect.jsp\#. } \\
\text { Data for occurences of all tropical cyclones within } 100 \mathrm{~km} \text { of Laguna Salada data obtained from: } \\
\text { http://www.csc.noaa.gov/hurricanes/\# }\end{array}$} \\
\hline Variable & $\begin{array}{l}\text { Chi- } \\
\text { square }\end{array}$ & $p$-value \\
\hline PDSI average for same month & 22.5 & 0.004 \\
\hline PDSI averaged 3 months prior & 29.4 & 0.000 \\
\hline PDSI averaged 6 months prior & 42.6 & 0.000 \\
\hline PDSI averaged 9 months prior & 24.8 & 0.002 \\
\hline Tropical cyclone occurrence for same month within 100 km & 1.3 & 0.254 \\
\hline Number of tropical cyclone occurences within $100 \mathrm{~km}$ in last 3 months & 2.4 & 0.120 \\
\hline Number of tropical cyclone occurences within $100 \mathrm{~km}$ in last 9 months & 2.1 & 0.148 \\
\hline Number of tropical cyclone occurences within $100 \mathrm{~km}$ in last 6 months & 1.9 & 0.172 \\
\hline
\end{tabular}




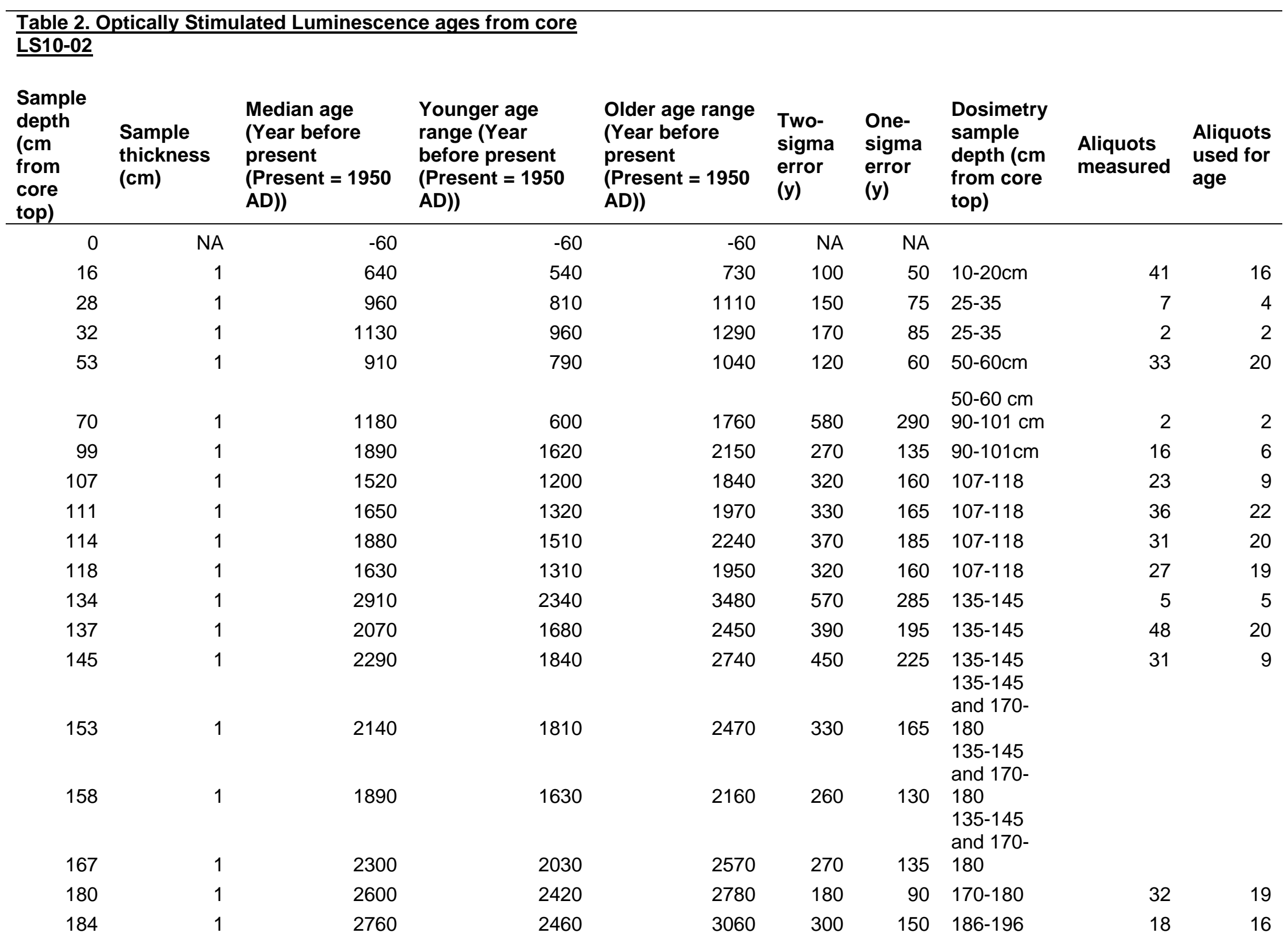




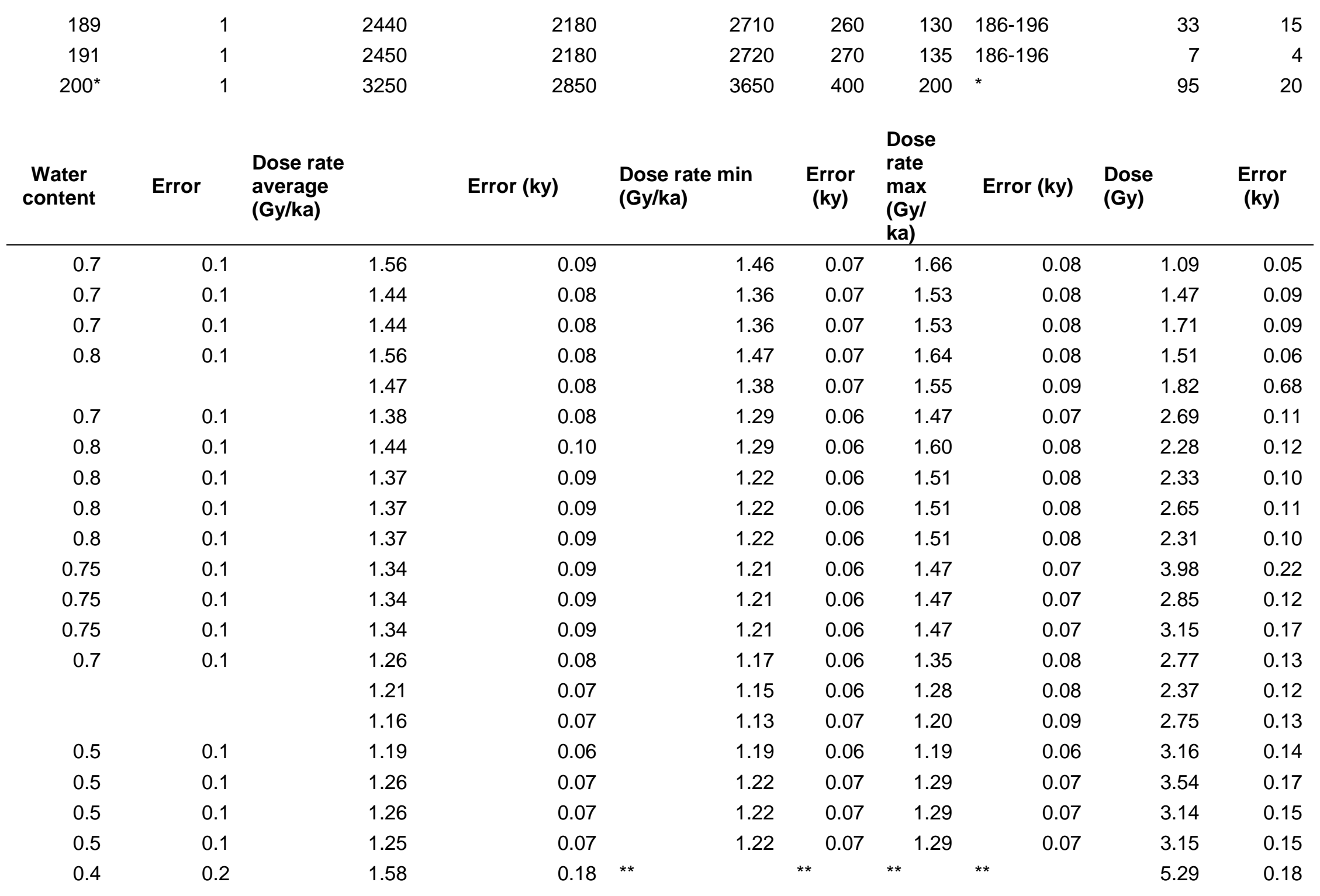

${ }^{*}$ OSL Sample from basal sand of playa 
sediments of adjacent core LS08-01

** Min and maximum dose rates are unavailble as gamma-spec settings were not set properly; only average dose rate calculations available.

\section{Table 3. Analysis of monthly PDSI control upon monthly Laguna Salada, Texas dry/full} phases

Explanation

Measure of dependence, using Chi-square statistic, between monthly PDSI data and monthly Laguna Salada dry/full phases derived from aerial and satelite imagery from 1972 to 2003.

Chi-squared measure of dependence on dry/full phases for $n$ months following August of each year.

$n$ months following August assigned either dry or full by vote (e.g. for 3 moths after August if 2 of 3 months dry then entire 3 month period assigned as dry)

Palmer Drought Severity Index (PDSI) data for South Texas Region 9 and downloaded from:

http://www7.ncdc.noaa.gov/CDO/CDODivisionalSelect.jsp\#.

\begin{tabular}{|c|c|c|c|c|c|c|c|}
\hline \multirow[b]{2}{*}{ Variable } & \multicolumn{2}{|c|}{3 months after August } & \multicolumn{2}{|c|}{6 months after August } & \multicolumn{3}{|c|}{$\begin{array}{l}9 \text { months after August } \\
\text { Chi- }\end{array}$} \\
\hline & Chi-square & $p$ value & Chi-square & $p$ value & square & $p$ value & \\
\hline June PDSI & 5.5 & 0.48 & 8.2 & 0.31 & 6.4 & & 0.49 \\
\hline July PDSI & 18.7 & 0.01 & 15.7 & 0.03 & 8.3 & & 0.31 \\
\hline August PDSI & 15.1 & 0.03 & 13.3 & 0.06 & 15.0 & & 0.04 \\
\hline June, July, August PDSI & 15.4 & 0.02 & 14.1 & 0.05 & 7.6 & & 0.37 \\
\hline
\end{tabular}

